\author{
Alicia Chabert \\ Universitat Jaume I (UJI), Spain
}

\title{
A PLURILINGUAL APPROACH TO ELT IN PRIMARY SCHOOL: TOWARDS AN ECOLOGICAL PERSPECTIVE
}

Summary. This paper aims to demonstrate that using a plurilingual and ecological approach to English language teaching can achieve better results in primary school independently of the mother tongue of the student. This article is based on the initial results of our international research carried out in three very different countries (Norway, China and Spain). While the author's research project involves 328 participants, we will present the results of the first phase of the experiment, including 133 students. In this paper, we propose a plurilingual communicative approach to English teaching as a foreign language, making a distinction between languages for communication and languages for identification. This research examines the current teaching policies in the participating countries, and analyses cross-cultural and cross-linguistic perspectives in English language teaching while promoting the positive use of the mother tongue as a connecting tool in the students' communication system. The subjects of this study were divided in control and experimental groups, in which they received traditional and plurilingual approach respectively. After the classes they completed a test and were then supplied with a Likert scale questionnaire focused on understanding their attitude and motivation towards mother tongue and English language learning. Based on observation and results obtained, we can conclude that a plurilingual approach that uses L1 as a tool in English teaching improves English learning, as well as develops an ecological understanding of languages.

Keywords: plurilingual approach; L1 in English learning; language policy; language ecology; ELF.

\section{Introduction}

It is undeniable that the global influence of the English language is everywhere we look, whether this is in the media, education, science, tourism, or business. English has permeated all levels of society entering all kinds of domains (Seidlhofer, Breiteneder, \& Pitzl, 2006) and this is even more evident in Europe. It is the language of international communication par excellence worldwide but it has become the de facto lingua franca in Europe, where the need for intraEuropean communication pushed this language to take the position but the policies around it are still very controversial in a territory where multilingualism and language diversity is one of the main core values. It is this current status that has awoken many relevant research topics such as linguistic imperialism, 
the varieties of English, linguistic diversity and conservation, or linguistic and cultural identity, which are often focused in the use of language and not so much integrated in the study of language acquisition. Our research focuses on English language teaching in a plurilingual society and aims to propose a sustainable approach to teach a language that acts as a lingua franca using the first language to learn the second one more effectively while exalting the value of the mother tongue.

In a world populated by different "Englishes" and ruled by "nativeness," it is a complex matter to define what English as a Lingua Franca (ELF thereafter) entails and even more so to teach it as a second language, while at the same time disassociating the language from its "original native speakers" (British or American, for instance). The English language expanded with the British Empire through the colonies, it stayed dominant through the global markets and new technologies, and it has now taken the position of a global language that no longer belongs exclusively to the native speakers. The World Englishes model "does not appear to take into account the fact that English has acquired a new dominant function world-wide" (Mollin, 2006, p. 42) and this has inspired many different research fields within ELF. Despite the different views and understandings of ELF, the idea of the plurilithic English is the common ground, where the focus of international communication is on intelligibility across groups of English speakers of different first language backgrounds (Mckay, 2018). However, not all scholars are on the same page in terms of defining what it actually is and what it represents. For some, ELF is conceptualised as an umbrella term to refer to a language function (Friedrich \& Matsuda, 2010; House, 2003), while for others it is becoming a new variety (Jenkins, Modiano, \& Seidlhofer, 2001; Seidlhofer, 2009) and focus on the characteristics of a certain group of speakers using English to communicate in an international setting. As an example, we can refer to two projects in Europe, VOICE (Vienna-Oxford International Corpus of English), led by Barbara Seidlhofer, and ELFA (English as a Lingua Franca in Academic Settings), led by Anna Mauranen, which are dedicated to investigating the nuances and common traits of English used by non-natives.

Nevertheless, we find the definition of ELF as a variety rather incomplete. 


\section{Defining ELF within a plurilingual and ecological perspective}

On the one hand, we agree with Friedrich and Matsuda's statement that understanding ELF "as merely a linguistic variety fails to capture the reality of EIL communication ${ }^{14}$, which is context and situation specific, and such failure is not only confusing but also detrimental" (2010, p. 26). On the other hand, by accepting ELF as a variety rather than a function, we accept it as a language that identifies and belongs to a certain group of people, which can, in time, hinder understanding between different varieties of ELF (therefore defeating its purpose) and can create confusion and fear of overtaking the mother tongue. Even though English in international and intercultural contexts is intended to serve as a lingua franca and is motivated by communicative needs and not (in theory) cultural factors, it is not easily separated from status and "native" culture. For this reason, teaching ELF faces great difficulties in its application. At present, the "authentic" materials used in the classroom are still predominantly British or American and overall the approaches used across the world are mostly monolingual and native-based. Native speaker models are still defining authentic materials and cultural appropriateness. It was expected that "uncoupling the language from its native speakers and probing the nature of ELF is a special methodological challenge" (Seidlhofer, Breiteneder, \& Pitzl, 2006, p. 21), nonetheless it is not the only one. There are two interrelated challenging factors to consider when approaching ELF teaching and researching: identity and multilingualism.

At the moment, with the spread of ELF, the relationship between language and identity are subject to radical changes as a consequence of cultural, political and linguistic internationalisation, "virtualisation" and globalisation (Cornillie, Lambert, \& Swiggers, 2009), and language is not always linked to a certain identity. There is now a dichotomy between English as a language for communication and a language for identification, and while English asserts its status as a language of prestige (Phillipson \& SkutnabbKangas, 1997), the internet has facilitated the revitalisation of some minority

${ }^{14}$ In this case EIL (English as an International Language) and ELF are equivalent. 
languages (Ferre-Pavia, Zabaleta, Gutierrez, Fernandez-Astobiza, \& Xamardo, 2018). With the advancement of technology and the constant contact between languages, not only geographically but virtually, multilingualism has become more evident as our current reality and monolinguals have become the exception (De Bot, 2019; Schmitz, 2014). In the words of Julianne House (2003, p. 561) "the very spread of ELF may stimulate members of minority languages to insist on their own local language for emotional binding to their own culture, history and traditions". Linguistic identity is less unitary than ever and it has become even more multi-faceted and eclectic, yet language is still extremely sensitive to the characteristics that serve as key markers of group identity (Phillipson, 2003, p. 25). Therefore, it should not be ignored in the classroom and syllabus planning. English teaching should not aim to create native speakers but ELF users respecting their own mother tongue and identity. Plurilingualism goes hand in hand with the spread of ELF and, consequently, there is need to focalise on the development of plurilingual competences in the classroom. Our approach is based on a two-sided perspective: A plurilingual approach that involves the use of the L1 to develop the student's plurilingual competence and improve the learning of a new language, in this case, English; and, an ecological approach that proposes not only the use of L1 but presenting English as a language that is used for international communication and is not linked to any nation. Teaching English using an ecological involves not only focusing on the use of the mother tongue to learn a new language but also focusing on the fact that both languages are equally important in their own way within the language ecosystem. Haugen (1972) first referred to the ecology of language as "the study of interactions between languages and their environment (both social and natural)", and since then ecolinguistics has become an encompassing interdisciplinary field that is gradually gaining importance in a moment when English is the overall dominant language and any language could potentially be at risk. The question becomes how to develop a lingua franca at the disposal of everyone (not just the elite) maintaining diversity and the vitality of the rest of languages while respecting the speakers' identity and not imposing the social and cultural ideas rooted within the lingua franca. Mühlhäusler (2003, p. 234), in his paper on language 
endangerment and revival, defined the characteristics of language ecology as follows:

1. Considerations not just of system internal factors but wider environmental considerations

2. Awareness of the dangers of monoculturalism

3. Awareness of the limitations of both natural and human resources

4. Long-term vision

5. Awareness of those factors that make for the health of ecologies

Following these characteristics, it can be clearly observed that language ecology is intrinsically linked to plurilingualism and language policy. At present, the status of English and the growing awareness of its function as a global communication language makes it different from any other foreign language (Sifakis et al., 2018, p. 160), for this reason a real plurilingual and ecological approach is necessary to be included in education guidelines and real practice.

\section{English learning in primary school: the case of Europe}

On the one hand, Europe constitutes a mosaic formed by different countries and languages that have historically represented the identity of their speakers. Unlike Africa or Asia, Europe has generally been linguistically segregative and territory-bound (Cornillie et al., 2009). On the other hand, the current use of English as a common means of communication creates a "potential conflict with the ideals of societal multilingualism and individual plurilingualism" (Seidlhofer et al., 2006).

The education policies of the Council of Europe have evolved according to the changes in European society and have tried to provide guidelines (such as the CEFR or the European Language Portfolio) for institutions, teachers and learners. The Common European Framework of Reference is "a common basis for the elaboration of language syllabuses, curriculum guidelines, examinations, textbooks, etc. across Europe" (p. 1) that aims to encompass a plurilingual approach for all countries. With the CEFR and other complementary regulations, the Council of Europe aims to promote not only English but all languages and emphasises that only "through a better 
knowledge of European modern languages it will be possible to facilitate communication and interaction among Europeans of different mother tongues in order to promote European mobility, mutual understanding and cooperation, and overcome prejudice and discrimination" (Council of Europe, 2001 , p. 2). Europe embraces plurilingualism, and with its guidelines (Council of Europe, 2018; Jones \& Saville, 2009; North \& Piccardo, 2016) aims to provide a focus on communicative language competence, an understanding of the different components of plurilingual and intercultural education and possible approaches to implementing them. Some of the current language education policies are the "language friendly school", lifelong and early learning, CLIL (Content and Language Integrated Learning), the use of Information and communication technologies (ICTs), among others. Nonetheless, they are all very different proposals that generally not only do not take into account the different resources and preparation of different contexts, but also do not consider the impact on and from the mother tongue in language learning. These guidelines require real application within the complexity of specific contexts. Each country has its own micro-climate, some are monolingual in nature and others multilingual, and for this reason the language learning processes differ among them. At the same time, English does not occupy the same status nor is it used for the same purposes across Europe. In fact, in order to illustrate this, we will present two very different European landscapes in this paper: Spain and Norway.

The general proficiency level of both countries can be compared using the national level competence statistics (EF English Proficiency Index), which English First have been measuring since 2007. In the latest edition of its English Proficiency Index (EPI), 88 countries participated and, based on the results, Spain is currently in the $32^{\text {nd }}$ place, whereas Norway enjoys a very high $4^{\text {th }}$ position worldwide. Despite both countries being in Europe and receiving the same European guidelines, the results and applications are very different due to different factors, including socio-economic, linguistic, historical, and so forth. We will first focus on Spain, its current education system, its approach to English learning and socio-historic multilingual context.

Aside from the Spanish language, Spain is the home of three regional official languages (Basque, Catalan and Galician), which are spoken by 
approximately 15 million speakers in total (i.e. including any of the three minority languages) and are the centre of many polemical debates. This multilingual nation is attempting to achieve proficiency levels similar to its European neighbours without fully tackling its internal and controversial language diversity. Despite the fact that research supports that bilingualism favours third language acquisition (Cenoz, 2013; Jessner, 2006) and the country has been aiming for a plurilingual approach, the guidelines are still unclear. Foreign languages are being given a certain status and attention, and when referring to "plurilingualism" it is always from a foreign language perspective, and, specifically from an English perspective. The current law (LOMCE, Ley Orgánica 8/2013 para la mejora de la calidad educativa) declares that the Law strongly supports multilingualism, redoubling efforts to ensure that students are fluent in at least one foreign language, whose level of oral and reading comprehension and oral and written expression is decisive in favouring employability and professional ambitions, and for this reason it is strongly committed to the incorporation of a second foreign language into the curriculum (own translation, Jefatura del Estado, 2013, p. 10). This exemplifies the confusion in the different understandings of the European guidelines. Even though this law mentions "at least one foreign language" this refers to the English language only, and when it refers to multilingual and plurilingual education, only foreign languages are the focus, placing the mother tongue (whether national or regional) at a secondary level. Based on the Council of Europe, plurilingual education has two goals "adding to the linguistic and cultural resources which make up individual repertoires, using the available means efficiently. It covers the teaching of all languages, be they languages of schooling, foreign languages, regional or minority languages, or classical languages" and encouraging individuals to "respect and accept diversity of languages and cultures in a multilingual and multicultural society" (Beacco et al., 2016, p. 15). It is here where the Spanish education law fails to understand the European guidelines, since it mainly focuses on developing the student's English skills and underestimates the value of the mother tongue in multilingualism.

It is worth mentioning, however, that each autonomous region in Spain has specific additional education legislations to the national guidelines, and, on 
top of that, several projects sponsored by the European Union have also been implemented over the past few decades in different schools resulting in a very different landscape across the country. In particular, these projects focus on the use of English as a language of instruction. The CLIL (content and language integrated learning) has been the most popular application of plurilingual approach and even though any language could be used as a medium of instruction, the focus has been English as a lingua franca. One of these projects is the Bilingual Education Project (BEP), applied in 74 primary schools and 40 secondary schools, where the students learn English and Spanish through an integrated content-based curriculum (Dobson, Pérez Murillo, \& Johnstone, 2010). On the other hand, in the area where we based our study, which is a bilingual Catalan region, another plurilingual project named Plurilingual Plan was recently implemented. This program was approved in 2018 (Les Corts Valencianes, 2018) in the Valencian region and involves the division of subjects by language so that the students are exposed to three languages: Spanish, Catalan and English. This program originally was intended to provide support to the minority language as well as focusing on Spanish (majority language) and English (foreign language), maximising the communicative competence in different languages by creating contexts in which those languages are to be used. Yet, it was very controversial and poorly accepted, resulting in its partial nullity for allegedly discriminating against the majority language. Despite the polemical aspects, the program focuses on increasing the opportunities to use a certain language, but from a monolingual approach, since it does not allow more than one language to be used in a specific setting and keeps all languages from interacting with each other. The program proposes a guideline of hours to be used in each language and the schools can choose which language is used for a particular subject. The curricular content taught in a foreign language ${ }^{15}$ will fluctuate between $15 \%$ and $25 \%$ of teaching hours depending on the decisions of the education centre in question. Most schools choose English to teach Art (or in fewer cases Social Sciences) and in this case, only English is used, rather than using a plurilingual approach. Even though this program claims to be plurilingual, it fails to use a wholesome plurilingual

${ }^{15}$ Every time a foreign language is mentioned in Spanish guidelines it always refers to English in practical terms. 
approach. While it is true that education in Spain is moving in the right direction, language ecology is still a generally "foreign" concept and linguistic awareness has yet to gain the relevance it deserves in language acquisition and plurilingualism.

On the other end of the spectrum, we find Norway. English became a school subject in Norway towards the end of the 19th century (much earlier than in Spain, in the 1970s), which meant that in the 20th century English language awareness was well established. The English language in Norway is everywhere, in the media (while Spain traditionally has always dubbed films, Norway opted for original versions with subtitles), higher education, business (it is used as a lingua franca in major companies). At the same time, there is a typological similarity between present-day English and the Mainland Scandinavian languages (Bech \& Embley Emonds, 2016), which provides certain advantages when learning the language. Norwegians currently use English as their second language, even though they would be classified as pertaining to the expanding-circle as per the traditional Kachruvian model (Kachru, 1990), and it is this transitional status of English in Norway that reflects "the negotiation between global development and local appropriation which characterises English in the world today" (Rindal \& Piercy, 2013, p. 212). In terms of pedagogy, Norway went through a similar language teaching process to Spain, shifting from a grammar-translation based approach to audio-lingual and to, finally, communicative. The current curriculum focuses mainly on communicative competence as the Spanish curriculum does, but unlike Spain, it has also focused on the idea of English as a global language. Not only does the English curriculum focus on international communication but also on the idea of "English-speaking" world, aiming to avoid focusing on the traditional British or American English:

"The subject of English shall provide insight into how English is used as an international means of communication. Learning about the English-speaking world and the increasing use of English in different international contexts will provide a good basis for understanding the world around us and how English developed into a world language." (KD, 2006 p. 1) 
Spain, on the other hand, references the CEFR and remains ambiguous when referring to socio-cultural aspects to be learnt, not specifying the culture it refers to in the national curriculum. Nonetheless, the textbooks used in the schools clearly focus on British or American English language and culture, and also, all immersive projects focus specifically on the British variety, since they are partly funded by the British Council.

As it can be observed, while both Spain and Norway are under the umbrella of the European guidelines, they differ greatly in the way language for international communication is understood and how language teaching is implemented. Not only does Norway have a greater focus on English as an international global language, but it is also more familiar with the concept of language ecology, as we observe in the objectives of the Norwegian English curriculum where we find the following statement: "the main focus is on seeing what is involved in learning a new language and seeing relationships between English, one's native language and other languages" (KD, 2006, 2010, p. 2). Further down in the curriculum, the following specific competences can be found: "identify some linguistic similarities and differences between English and the native language", which involves the development of plurilingual competences, and "compare the way people live and socialise in various cultures in English-speaking countries and in Norway, including the Sami culture" (KD, 2006, 2010, p. 4), which refer to the development of intercultural competences. This different perspective develops language awareness and positively uses cross-linguistic influence to help the learner understand linguistic structures and principles in different languages, making the language learning process easier (Jessner, 2006; O'Neill, Bennett, \& Vanier, 2010). We can conclude then that both countries aim to follow a plurilingual approach from different perspectives and in turn achieve different results within their respective contexts. These differences can be observed in the students' attitude towards English and their mother tongue, which was analysed through a survey and will be presented in the section below. 


\section{The study: objectives and participants}

The background to our study is based on our personal experience as English language teachers in different countries in Spain, Norway, China, and South Korea. Our first-hand experience observing the impact of L1 in L2 learning and difficulties in second language learning was the basis of our current research project. Our study focuses on three main areas: a plurilingual approach to English learning, English as a lingua franca, and in-context language policies. We combine these three different points in a study that, in short, attempts to prove that a plurilingual language approach to English teaching will improve the learning of the language (independently of the mother tongue) as well as promote an ecological approach. This whole study is the base for the author's unpublished doctoral dissertation, which includes three countries: Norway, China and Spain. Nevertheless, this paper will refer only to the data currently available from some of the schools in Spain and Norway.

Below we will present the results obtained in the following schools: one centre in Levanger (Norway) with 39 students, and two in Castelló (Spain) with 94 students in total. Unfortunately, the results obtained from the school in Borriol (Spain) had to be excluded due to noncompliance with our requirements. While this study includes the schools mentioned above, it is a part of a bigger project, including two primary schools in China (Shenzhen and Changsha) with 149 students, and another one in Spain with 46 students.

Table 1.

Schools and number of participants

\begin{tabular}{|l|l|}
\hline School & Number of participants \\
\hline $\begin{array}{l}\text { School 1 Castelló, Spain } \\
\text { (middle-upper urban area) }\end{array}$ & 53 students \\
\hline $\begin{array}{l}\text { School } 2 \text { Castelló, Spain } \\
\text { (middle-low urban area) }\end{array}$ & 41 students \\
\hline $\begin{array}{l}\text { School } 3 \text { Levanger, Norway } \\
\text { (middle rural area) }\end{array}$ & 39 students \\
\hline
\end{tabular}


The study focuses on the students in the Year 6 of primary school (1011 years old), since at that age they have a minimum basis of English (at least A1 in the CEFR level) and are able to follow a class in English only. The teachers of the schools were also participants in the study in a different way from the students, since semi-structured interviews were carried out to provide further information about the school and their students, as well as their attitudes towards specific teaching approaches.

\section{Method and results}

In order to support our hypothesis that students learn better using a plurilingual approach, we prepared a lesson plan using a subject that was common in both countries in Year 6 students in Primary School. In both cases, the students started learning English at the age of 6 . The participants were divided in two groups (control and experimental) in each school, and a combined action and experimental methodology was used. One group received an English lesson using a plurilingual approach and the other one a monolingual approach. Because Norway already uses a plurilingual approach, the control group was the plurilingual one and the experimental was the monolingual, whereas it was the opposite in Spain. Before starting the project, we carried out interviews with the English teachers to find a subject that would be adequate but had not yet been studied in the classroom ${ }^{16}$.

The experiment was divided in two classes of 50 minutes each: the first class was dedicated to the lesson and the other one for revision, the test, and was followed by a survey to evaluate their attitude towards the mother tongue and English. The grammar and vocabulary concepts focused on prepositions of place and direction, giving and understanding directions and using the imperative. In the class where the plurilingual approach was used, we explained the grammar concepts comparing them to the mother tongue and using the $\mathrm{L} 1$ for instruction when needed. In this class we used conversation examples that used code-switching in different languages to illustrate that the

\footnotetext{
${ }^{16}$ It was on these grounds that we had to disqualify the school in Borriol. Unfortunately, upon completion of the study, the students confirmed they learnt the concepts provided in the project lesson plan during the previous year unbeknownst to the current teacher.
} 
speakers may not always be native, but that English is used as a common ground for international communication as a tool. In the class where the monolingual approach was used, the grammar concepts and vocabulary were taught using only English through drills, repetitions, and grammar inherent exercises. All examples provided were in English only. For the second class in both groups, we carried out a written test (see Appendix 1), an oral activity, and a survey. The written test was comprised of three written activities:

- A comprehension one where we provided a map and different directions in English and the students had to write down the location where the directions took them.

- A vocabulary one that combined production and comprehension. The learners had to fill the gaps in a conversation.

- And a production one, where the students had to create a conversation between two people asking and providing directions.

We excluded from the test any participants with special needs, as their results would have affected the reality of the approaches. In this study, we also considered the following factors that could affect the scores: bilingualism in any language and after-school English tutoring. Before the experiment started, the students had filled out a form stating whether they received any English tutoring after classes, the languages they use ( $L 1, L 2, L 3 \ldots)$ and whether they had contact with English realia (TV, books, comics) outside of the school environment. Interestingly, except for 2 students, all students in both Spanish schools received English classes after school, whereas no one in the Norwegian school received them. On the other hand, all students were bilingual (or trilingual) in the Spanish schools, as they live in a bilingual region. However, the Norwegian school was monolingual despite the amount of diverse minority languages spoken in Norway. In general, all students in Norway watched TV in English at least 3 times a week, whereas in the Spanish school it was almost never or never. Due to the length limitation on this article, we will focus on the written test results and a small part of the survey focused on the students' view of the importance of their mother tongue and English. Furthermore, at the moment of the writing of this paper we are still carrying 
out the project in China, hence only the Spanish and Norwegian test results are available (see figures below). The results of the written tests in two of the schools in Spain and the one in Norway can be observed in the figure below. We have divided the results of the figure into six sections, one for each activity in each approach. PA refers to plurilingual approach (English and mother tongue) and MA to monolingual approach (English only). The three different types of activities included: production, filling the gaps and comprehension.

\section{Plurilingual versus monolingual approach}

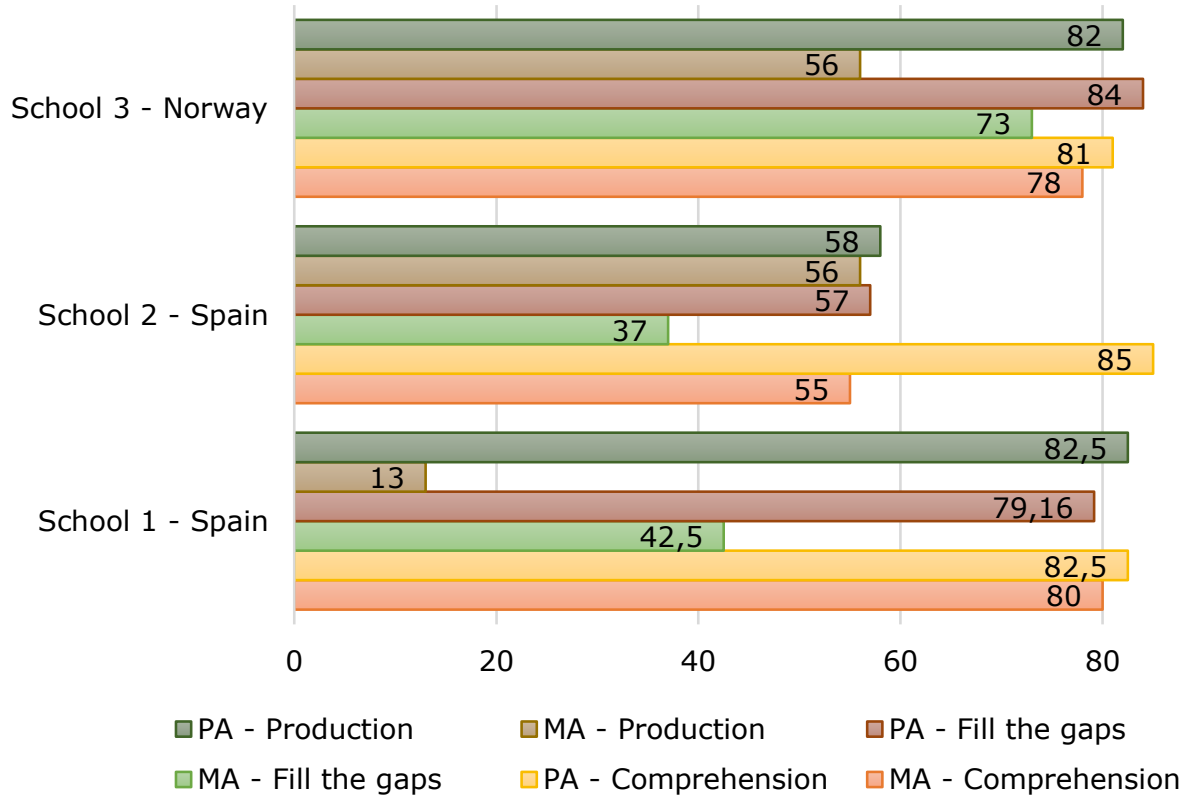

Fig. 1 Written test results

\section{Discussion}

In addition to the test results, our observations during the classes will be analysed below to provide a more holistic understanding of the research findings. As it can be observed in the figure above, the Norwegian school achieved better results than the Spanish ones. On the one hand, this was 
expected given the previously stated factors such as the contact with the English language outside of the school environment and a closer distance between the languages. On the other hand, based on our observation, the Norwegian students demonstrated a high linguistic awareness given the plurilingual nature of the classes they receive as part of their current education system. This was supported with the results obtained in the survey carried out in the schools, which was divided in two sections: the value of the mother tongue, and the value of English. On the graph below, we can see a representation of the students' attitudes towards English and their mother tongue based on the results obtained:

\section{Spain 1}

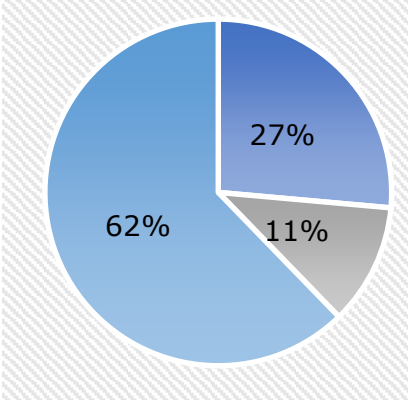

Spain 2

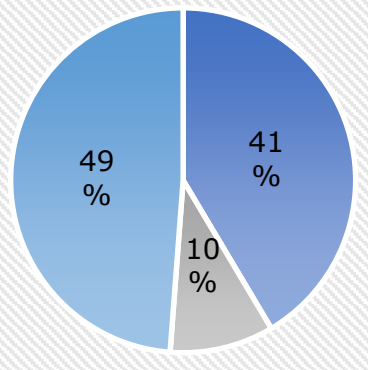

Norway

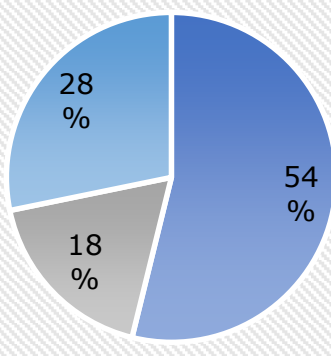

\begin{tabular}{|l|l|}
\hline & English is more important than my mother tongue \\
\hline & My mother tongue is as important as English \\
\hline & My mother tongue is more important than English \\
\hline
\end{tabular}

Fig. 2 Survey results

The fact that the Norwegian curriculum focuses on the equal importance of languages and uses a plurilingual approach has an impact on the students' perception of language and their attitude toward their mother tongue. With regard to the different activities of the test, the most differences obtained in the results were in the production exercise. In the classroom where a plurilingual approach was used, the students understood grammar considerably faster than the other group and were able to assimilate it better 
than when the monolingual approach was used. Even though this was a short study of two classes of $50 \mathrm{~min}$ ( 1 hour and $40 \mathrm{~min}$ in total), these initial results are a good starting point for a longer-term study to support the original hypothesis. As for the Spanish schools, they both achieved similar results using monolingual and plurilingual approaches for the first activity (the comprehension one) but very contrasting ones on the other two (gap filling and production) in favour of the plurilingual approach. In the Spanish schools, when the plurilingual approach was used the students' behavioural response was better compared to the monolingual one. In the class where only English was used, some students failed to maintain attention in class and, when this was queried, they confirmed that they did not understand all the content, so they were less interested. When giving instructions or explaining certain concepts, hence using $L 1$ in a "supportive and facilitating role in the classroom" (Tang, 2002, p. 39), the concentration and response from the students varied considerably between the two approaches. Using a plurilingual approach, all students in the three schools were able to understand instructions better and were more willing to participate and ask questions when the use of L1 was not treated as an error but as a tool to get to a different point.

With regard to the oral impact of both approaches, we carried out an oral activity in pairs that was recorded for further analysis. In this activity we showed a giant map to the whole class and the students had to enact in pairs a situation in which they were looking for directions and were given instructions to get to the requested place. We allowed the students in the plurilingual group to use their mother tongue (up to three words) if they were stuck, while the students in the monolingual group were only able to use English. We observed that in the plurilingual approach the students' fluency improved when they were not afraid to use some words in their mother tongue if they went blank, improving the overall communication. In this experiment we were able to introduce language ecology in the classroom and present English as a global language, but we were not able to observe the long-term impact, given the time restrictions for this project. Nevertheless, our initial observations and results seem optimistic extrapolating from the responses of the Norwegian students, whose English teachers used a plurilingual approach, 
and the current teaching guidelines in Norway. In order to use an ecological approach, we presented some examples within the related subject (giving and asking directions) from non-native speakers. The students were prompted to identify if any non-English word was used (in all instances they recognised them) in the example and we discussed the different realities of English speakers, i.e. not all are natives and English is used for international communication among different L1 speakers. The students were encouraged to acknowledge the fact that the speakers will not always use the expected and studied vocabulary and structure, but to accept that English is a communication language. For instance, a Spanish speaker may reply with "nothing" instead of "you are welcome" as a direct translation of the Spanish equivalent or a French speaker may, for instance, say the sentence "where is the boulangerie?" rather than "where is the bakery?", because it is a French word borrowed in English, even though the use is not nearly as common as bakery. When the examples were shown to the monolingual approach class in Spain, no prompting was given to the students about the example and they were requested to see the example and identify if there was anything different or unexpected. While they identified the foreign words in the example, the students' response was to classify them as errors, except in the Norwegian school. Although our experiment focuses mainly on the positive results of the plurilingual approach, we believe that this approach is linked to language ecology and that, if this approach was used over a longer period of time, there would be a difference in attitude towards the mother tongue. Using the Norwegian school system as a reference point, which uses the plurilingual approach as the norm, and our initial study results, we can observe how teaching the use of English as an international language and using one's mother tongue in language learning promotes a healthy response to interlanguage and code-switching, therefore seeing them as a trait but not as an error (Jenkins, Cogo, \& Dewey, 2011, p. 289). At the same time, presenting the students' mother tongue ${ }^{17}$ as a tool to learn English, rather than maintaining L1 as a separate construct (Cook,

\footnotetext{
${ }^{17}$ In the Spanish schools, we used both Spanish and Catalan as mother tongues given the bilingual nature of the region. In terms of any students of different heritage participating in the study, they all confirmed using Spanish, Norwegian or Catalan as one of their mother tongues.
} 
2001), develops the students' plurilingual competence and helps them learn English.

\section{Conclusions and limitations}

Based on the evidence we obtained from the current data and the literature explored, we confirm the idea that the plurilingual approach encourages the use of different languages to develop the learner's plurilingual competence, which in this case would help the students learn English. At the same time, this approach includes the mother tongue as a key asset in the linguistic repertoire, resulting in a positive attitude towards one's language and promoting a sustainable perspective. The findings of this study, however, have to be seen in light of some limitations, the first one is the unbalanced number of students and schools per country, which depended on the geographical area, national guidelines and availability. Secondly, the study was influenced by time restrictions allocated to the author's dissertation research by the university, as well as the self-funded nature of the project. Despite these current limitations, we believe that these initial findings contribute to the emerging global picture ELF teaching and the current guidelines on English language teaching in different countries. The data we have presented belongs to a broader ongoing study involving other languages, learning styles and students. The final results, to be published in 2020, include Sinitic, Latin and Germanic language families as mother tongues of the students. Yet, the author suggests that this investigation is followed with a longitudinal study to evaluate the implication of this approach long-term.

In this paper, we focused on the current situation of English as a lingua franca in Europe and propose that, from an early age, learners should understand the use of English for international communication within a larger ecosystem in which all languages are important. With our research findings, we demonstrate the potential of the mother tongue as a scaffolding tool to learn English while approaching English language teaching from an international and ecological perspective. By providing an international view we can observe how a plurilingual approach can improve the English learning process and proficiency, as well as provide hope for the coexistence of 
languages with a lingua franca. Our research demonstrates that a plurilingual approach can be applicable and beneficial to English learning in different countries and that an ecological perspective is needed to support a plurilingual approach in the classroom. Also, as it was demonstrated with the positive survey and test results obtained in Norway, the language learning guidelines used in a specific country need to keep the mother tongue in consideration when drafting their internal policies in order to maintain sustainable multilingualism.

\section{References}

Beacco, J. C., Byram, M., Cavalli, M., Coste, D., Cuenat, M. E., Goullier, F., \& Panthier, J. (2016). Guide for the Development and Implementation of Curricula for Plurilingual and Intercultural Education. Strasbourg: Council of Europe Publishing.

Bech, K., \& Embley Emonds, J. (2016). English is (still) a West Germanic language. Nordic Journal of Linguistics, 39(1), 65-100. doi: $10.1017 /$ S0332586515000219.

Cenoz, J. (2013). The additive effect of bilingualism on third language acquisition: A review. Language Teaching, 46(1), 71-86. doi: $10.1017 /$ S0261444811000218.

Cook, V. J. (2001). Using the First Language in the Classroom. The Canadian Modern Language Review, 57(3), 402-423. doi: $10.3138 / \mathrm{cm} \mid r \cdot 57.3 .402$.

Cornillie, B., Lambert, J., \& Swiggers, P. (2009). Linguistic identities, language shift and language policy in Europe. Leuven: Peeters.

De Bot, K. (2019). Defining and Assessing Multilingualism. In J. W. Schwieter (Ed.), The Handbook of the Neuroscience of Multilingualism (p. 880). Hoboken: John Wiley \& Sons.

Dobson, A., Pérez Murillo, M. D., \& Johnstone, R. (2010). Programa de educación bilingüe en España. Informe de evaluación. Madrid: Ministerio de educación y British Council.

EF English Proficiency Index, (2018). Retrieved from https://www.ef.com/ca/epi/. 
Ferre-Pavia, C., Zabaleta, I., Gutierrez, A., Fernandez-Astobiza, I., \& Xamardo, N. (2018). Internet and Social Media in European Minority Languages: Analysis of the Digitalization Process. International Journal of Communication, 12, 1065-1086. Retrieved from https://ijoc.org/index.php/ijoc/article/view/7464.

Friedrich, P., \& Matsuda, A. (2010). When Five Words Are Not Enough: A Conceptual and Terminological Discussion of English as a Lingua Franca. International Multilingual Research Journal, 4(1), 20-30. doi: $10.1080 / 19313150903500978$.

Haugen, E. (1972). The ecology of language. Stanford: Stanford University Press.

House, J. (2003). English as a lingua franca: A threat to multilingualism? Journal of Sociolinguistics, 7(4), 556-578. doi:10.1111/j.14679841.2003.00242.x.

Jenkins, J., Cogo, A., \& Dewey, M. (2011). Review of developments in research into English as a lingua franca. Language Teaching, 44(3), 281-315. doi:10.1017/S0261444811000115.

Jenkins, J., Modiano, M., \& Seidlhofer, B. (2001). Euro-English. English Today 68, 17(4), 13-19. doi:10.1017/S0266078401004023.

Jessner, U. (2006). Linguistic Awareness in Multilinguals: English as a Third Language. Edinburgh: Edinburgh University Press.

Jones, N., \& Saville, N. (2009). European Language Policy: Assessment, Learning, and the CEFR. Annual Review of Applied Linguistics, 29, 5163. https://doi.org/10.1017/S0267190509090059.

Kachru, B. B. (1990). World Englishes and Applied Linguistics. World Englishes, 9(1), 3-20. doi:10.1111/j.1467-971X.1990.tb00683.x

Mckay, S. L. (2018). English As an International Language: What It Is and What It Means for Pedagogy. RELC Journal, 49(1), 9-23. doi: $10.1177 / 0033688217738817$.

Mollin, S. (2006). English as a Lingua Franca: A New Variety in the New Expanding Circle? Retrieved from https://pdfs.semanticscholar.org/8820/85b9b273f3b6788829e53d90 b4de002eb2c2.pdf. 
Mühlhäusler, P. (2003). Language endangerment and language revival. Journal of Sociolinguistics, 7(2), 232-245. doi:10.1111/1467-9481.00221.

North, B., \& Piccardo, E. (2016). Common European Framework of Reference for Languages: Learning, Teaching, Assessment Developing Illustrative Descriptors of Aspects of Mediation for the CEFR. Strasbourg: Council of Europe Publishing.

O'Neill, B., Bennett, J., \& Vanier, C. (2010). Crossing linguistic boundaries: Making the most of cross-linguistic influence in the language classroom. Working Papers of the Linguistics Circle of the University of Victoria, 20, 50-62. Retrieved from https://pdfs.semanticscholar.org/adef/c623f5b7e5c5bf36dd7aa9c951f bee010635.pdf.

Phillipson, R. (2003). English-Only Europe? London: Routledge.

Phillipson, R., \& Skutnabb-Kangas, T. (1997). Linguistic human rights and English in Europe. World Englishes, 16(1), 27-43. doi:10.1111/1467$971 \times .00044$.

Rindal, U., \& Piercy, C. (2013). Being "neutral"? English pronunciation among norwegian learners. World Englishes, 32(2), 211-229. doi: $10.1111 /$ weng. 12020 .

Schmitz, J. R. (2014). Looking under Kachru's (1982, 1985) three circles model of World Englishes: the hidden reality and current challenges. Revista Brasileira de Linguística Aplicada, 14(2), 373-411. doi:10.1590/S1984-63982014005000010.

Seidlhofer, B. (2009). Common ground and different realities: world Englishes and English as a lingua franca. World Englishes 28(2), 236-245. doi: 10.1111/j.1467-971X.2009.01592.x.

Seidlhofer, B., Breiteneder, A., \& Pitzl, M.-L. (2006). English as a lingua franca in Europe Challenges for Applied Linguistics. Annual Review of Applied Linguistics, 26. doi:10.1017/S026719050600002X.

Sifakis, N. C., Lopriore, L., Dewey, M., Bayyurt, Y., Vettorel, P., Cavalheiro, L., Kordia, S. (2018). ELF-awareness in ELT: Bringing together theory and practice. Journal of English as a Lingua Franca, 7(1), 155-209. doi: $10.1515 /$ jelf-2018-0008. 
Tang, J. (2002). Using L1 in the English Classroom. English Teacher Forum, 40(1), 36-43. Retrieved from

https://americanenglish.state.gov/files/ae/resource_files/02-40-1-

h.pdf.

\section{Regulations}

Council of Europe. (2001). Common European Framework of Reference for Languages: Learning, Teaching, Assessment.

Council of Europe. (2018). Common European Framework of Reference for Languages: Learning, Teaching, Assessment Companion Volume with New Descriptors.

KD. (2006). ENG1-03 - National Curriculum for Knowledge Promotion in Primary and Secondary Education and Training. English subject curriculum. Oslo: Ministry of Education and Research.

Les Corts Valencianes. (2018). Ley 4/2018, de 21 de febrero, por la que se regula $y$ promueve el plurilingüismo en el sistema educativo valenciano. Valencia: Generalitat Valenciana

Jefatura del Estado. (2013). Ley Orgánica 8/2013, de 9 de diciembre, para la mejora de la calidad educativa BOE. https://doi.org/BOE-A-2012-5403 
Alicia Chabert

Jaume I (UJI) universitetas, Ispanija; chabert@uji.es

\section{DAUGIAKALBIS ANGLU KALBOS MOKYMO METODAS PRADINĖJE MOKYKLOJE: EKOLOGINĖ PERSPEKTYVA}

Santrauka. Šiame straipsnyje nagrinejama, kaip daugiakalbis ir ekologinis anglu kalbos mokymo metodas padeda pasiekti geresnius rezultatus pradinejje mokykloje, nepriklausomai nuo mokinio gimtosios kalbos. Straipsnis paremtas pirminiais tarptautinio tyrimo, atlikto trijose labai skirtingose šalyse (Norvegijoje, Kinijoje ir Ispanijoje), rezultatais. Nors tyrimo projekte dalyvavo 328 dalyviai, straipsnyje aptariami 133 mokiniu pirmojo eksperimento etapo rezultatai. Straipsnyje aprašomas daugiakalbis komunikacinis anglu kaip užsienio kalbos mokymo metodas, atskiriant kalba komunikacijai ir kalba identitetui išreikšti. Tyrime nagrinèjama dabartinè mokymo politika tiriamose šalyse ir analizuojamos tarpkultūrinès ir lingvistinès perspektyvos anglu kalbos mokyme, kartu skatinant teigiama gimtosios kalbos vartojimą kaip jungiamaja priemonę komunikacinèje sistemoje. Tyrimo dalyviai buvo suskirstyti $i$ kontrolinę ir eksperimentinę grupes, kuriose buvo taikomi tiek tradiciniai, tiek daugiakalbiai mokymo metodai. Po kursu buvo laikomas testas ir pildomas Likerto skalès klausimynas, kurio tikslas buvo atskleisti dalyviu požiūri i gimtają ir anglu kalbas bei motyvacija jas mokytis. Remiantis stebèjimais ir gautais rezultatais galima teigti, jog daugiakalbis metodas, kuriame gimtoji kalba yra naudojama kaip irankis anglu kalbos mokyme, pagerina anglu kalbos žinias ir išvysto ekologini kalbu supratimą.

Pagrindinès sąvokos: daugiakalbis mokymo metodas; gimtoji kalba anglu kalbos mokyme; kalbos politika; kalbos ekologija; anglu kalba kaip lingua franca. 